DOI

\title{
ДЕСКВАМАЦІЯ ЕНДОТЕЛІОЦИТІВ АРТЕРІЙ НИЖНІХ КІНЦІВОК ПРИ ЕКСПЕРИМЕНТАЛЬНІЙ ГІПЕРУРИКЕМІЇ У ЩУРІВ ДОРЕПРОДУКТИВНОГО ТА РЕПРОДУКТИВНОГО ВІКУ
}

\author{
○І. І. Юрик' , Я. Я. Боднар ${ }^{1}$, М. М. Орел² \\ ${ }^{1}$ ДВНЗ «Тернопільський державний медичний університет імені І. Я. Горбачевського МОЗ України» \\ ${ }^{2}$ Комунальна установа Тернопільської обласної ради \\ «Тернопільське обласне патологоанатомічне бюро»
}

\begin{abstract}
РЕЗЮМЕ. При дослідженні особливостей десквамації ендотеліоцитів тварин дорепродуктивного та репродуктивного віку за умов гіперурикемії встановлено, що чисельність злущених ендотеліальних клітин суттєво зростає до 30-го дня експерименту та переважає у щурів репродуктивного віку.

Ремоделювання судинного русла проявляється потовщенням судинної стінки за рахунок гіперплазії і гіпертрофії лейоміоцитів з лімфоцитарно-макрофагальною інфільтрацією адвентицію.

КЛючОВІ СЛОВА: гіперурикемія, десквамовані ендотеліоцити, ремоделювання, артерії нижніх кінцівок.
\end{abstract}

Вступ. Із літературних оглядів стосовно впливу гіперурикемії (ГУ) на ремоделювання органів і тканин випливає, що більшість досліджень спрямовані на вивчення клінічних проявів подагри, нефролітіазу і артеріальної гіпертензії [1]. Водночас недостатньо уваги приділено віковим особливостям структурних змін судинного русла та ендотеліальній дисфункції при порушенні пуринового обміну.

У здоровому організмі ендотелій має низьку здатність до проліферації, а безперервність ендотеліальної вистилки забезпечується завдяки амітотичному поділу неушкоджених ендотеліоцитів. Ступінь порушення їх функції можна дослідити за збільшенням в периферійній крові кількості циркулюючих десквамованих ендотеліоцитів (ДЕЦ). Відомо, що зростання кількості ДЕЦ У крові спостерігається при гострих церебральних ішеміях [2], електротравмі [3], цукровому діабеті, ішемічній хворобі серця, гестозах вагітних $[4,5,6]$. Проте вплив ГУ на інтенсивність десквамації ендотеліоцитів залишається недостатньо вивченим. Одні автори вважають, що відновлення ендотелію та строми судинної стінки залежить від антиоксидантних властивостей сечової кислоти (СК), інші, навпаки, вважають, що їй притаманний ушкоджувальний вплив, який сприяє розвитку фіброзу i атеросклерозу [7, 8].

Мета дослідження - з'ясувати особливості десквамації ендотеліоцитів та ремоделювання артерій нижніх кінцівок у щурів дорепродуктивного та репродуктивного віку за умов гіперурикемії.

Матеріал і методи дослідження. Дослідження проведені на 32 білих щурах. До експериментальної групи увійшли 16 тварин із біохімічно підтвердженою ГУ, які були поділені на 2 групи: перша - 8 тварин чотиримісячного віку вагою 150-170 г і друга - 8 щурів віком 12 місяців вагою
230-250 г. Контрольну групу становили щури віком 4 і 12 місяців (по 8 тварин).

Визначення кількості циркулюючих в крові десквамованих ендотеліоцитів проводили за методом J. Hladovec (1978) в модифікації В. В. Сівак [9].

Гіперурикемію відтворювали за методикою О. В. Синяченка (2007) в модифікації Я. Я. Боднара та ін. $[10,11]$. Щурів протягом 45 днів утримували на білковій дієті з додаванням до їжі аутолізату дріжджів, який $\epsilon$ джерелом пуринів і нуклеїнових кислот, молібдату амонію для стимуляції ферменту ксантиноксидази, інозину, який $\epsilon$ попередником СК та кров'янки стандартного технологічного виробництва. При цьому тварини перебували в стані хронічного стресу, який моделювали шляхом вимушеного перебування у вертикальному положенні. Утримання щурів та всі експерименти виконані відповідно до положень «Європейської конвенції про захист хребетних тварин, які використовуються для експериментів та інших наукових цілей» (Страсбург, 1986), Загальних етичних принципів експериментів на тваринах, ухвалених Першим національним конгресом з біоетики (Київ, 2001), Гельсинської декларації Всесвітньої медичної асоціації (2000). Виведення лабораторних щурів з експерименту здійснювали шляхом інтраочеревинного введення великих доз тіопенталу натрію на 15-ий, 30-ий та 45-ий день. Біоптати тканин стегнового, підколінного і гомілкового сегментів фіксували в $10 \%$ розчині нейтрального формаліну і за стандартною методикою ущільнювали парафіном. Депарафінізовані гістологічні зрізи фарбували гематоксиліном і еозином, резорцинфуксином за Вейгертом та ван Гізон, фукселіном Харта, залізним гематоксиліном за Генденгайном та альціановим синім, толуїдиновим синім та ШИКреакцією. Рівень урикемії визначали в біохімічній лабораторії за загальноприйнятою методикою. В 
Огляди літератури, оригінальні дослідження, погляд на проблему

роботі з гістологічними препаратами використовували мікроскопи SEOSCAN, Люмам Р-8, МБИ-15. Зображення з мікроскопів виводили на монітор комп'ютера за допомогою відеокамери VISION Color CCD Camera i програми InterVideoWinDVR.

Результати й обговорення. Рівень СK у щурів дорепродуктивного віку, які перебували на гіперурикемічній дієті, на 15-ий день становив $(176,12 \pm 3,16)$ мкмоль/л, а в щурів репродуктивного віку - $(189,99 \pm 2,22)$ мкмоль/л, на 30-ий день - відповідно $(242,81 \pm 1,58)$ мкмоль/л і $(254,44 \pm 3,01)$ мкмоль/л і на 45-ий день -
$(256,09 \pm 2,39)$ мкмоль/л і $(268,67 \pm 4,09)$ мкмоль/л. У контрольній групі рівень СК становив у тварин дорепродуктивного віку $(116,83 \pm 1,77)$ мкмоль/л проти $(125,13 \pm 2,37)$ мкмоль/л у тварин репродуктивного віку. Інтима судин при експериментальній гіперурикемії зазнає структурних змін, які проявляються появою значної кількості десквамованих ендотеліоцитів. На 15-ий день експерименту кількість ДЕЦ в периферійній крові збільшувалася на $27,80 \%$ у статево незрілих тварин і на $34,25 \%$ у дорослих щурів $(p<0,05)$, що графічно відображено на рисунку 1.

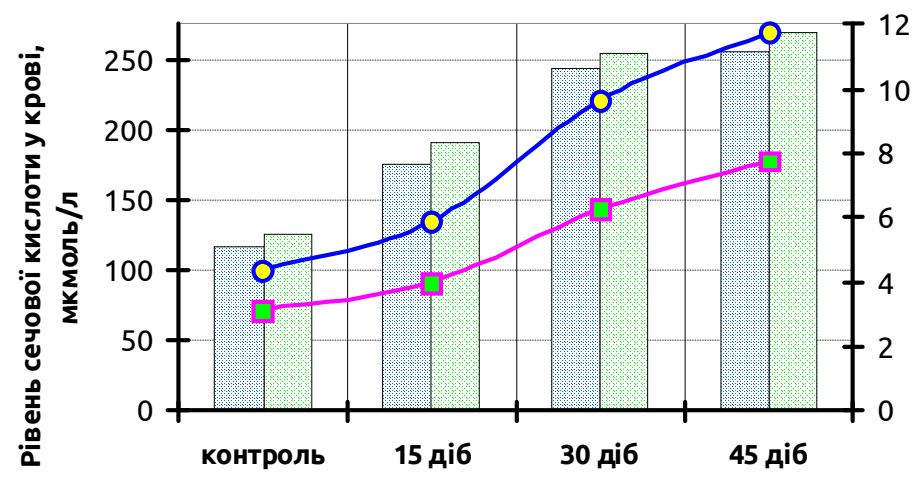

Терміни експерименту

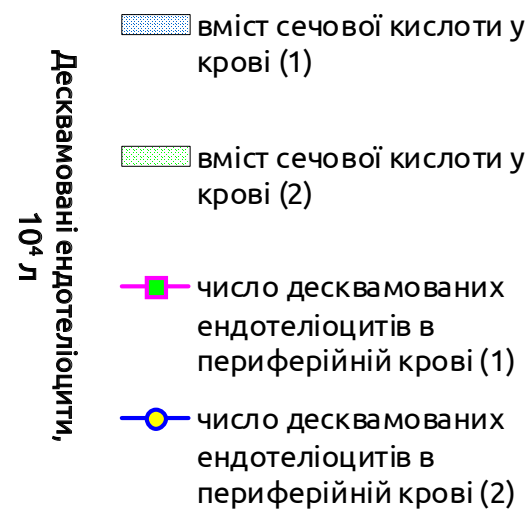

Рис. 1. Динаміка змін вмісту сечової кислоти та десквамованих ендотеліоцитів у периферійній крові піддослідних тварин у різні терміни експерименту.

На 30-ий день експерименту кількість ДЕЦ зростала у 2,26 раза і становила $(9,88 \pm 0,35) \times 10^{4} / л$ у тварин репродуктивного віку та у 2,00 рази в тварин дорепродуктивного віку, сягаючи $(6,25 \pm 0,49) \times 10^{4} / л$. При цьому вказана різниця $\epsilon$ статистично достовірною - $p<0,001$ та $p<0,01$ відповідно.

На 45-ий день експериментальної гіперурикемії рівень ДЕЦ у дорослих щурів зростав У 2,68 раза і становив $(11,75 \pm 0,45) \times 10^{4} / л(p<0,001)$, а у статево незрілих тварин - у 2,47 раза і становив $(7,75 \pm 0,25) \times 10^{4} / л(p<0,001)$.

Слід зазначити, що найсуттєвіше збільшення числа ДЕЦ спостерігається на 30-ий день експерименту, а саме - зростання у 2,26 раза у тварин репродуктивного віку, та у 2,00 раза у тварин дорепродуктивного. Переважання кількості десквамованої фракції ендотеліоцитів у щурів репродуктивного віку над тваринами дорепродуктивного віку зберігається і на 45-ий день дослідження. При мікроскопічному дослідженні десквамовані ендотеліоцити поліморфні. Зустрічалися клітини з пікнозом і рексисом ядер, а також із каріолізисом, набряком цитоплазми та ії частковою фрагментацією. Пошкоджені ендотеліоцити при злущенні оголюють інтиму, циркулюють з течією крові, що можна вважати структурною основою тромбоутворення в капілярах.

Згідно з нашими морфологічними дослідженнями, при експериментальній ГУ спостерігається гіпертрофічно-запальний тип ремоделювання судинного русла, що проявляється потовщенням судинної стінки за рахунок гіперплазії і гіпертрофії лейоміоцитів і лімфоцитарно-макрофагальною інфільтрацією адвентицію (рис. 2).

Узагальнюючи результати дослідження доцільно врахувати, що ендотеліоцити $\epsilon$ першим бар'єром між кров'ю та судинною стінкою і ГУ призводить до їх ураження шляхом нейрогуморальної стимуляції синтезу біологічно активних речовин, що беруть участь в ремоделюванні судинного русла. Важливе значення у процесі ремоделювання належить зниженню продукції ендотелієм NO-синтетази, яка запобігає адгезії лейкоцитів та тромбоцитів до судинної стінки, що сприяє тромбоутворенню, переміщенню моноцитів в підендотеліальний шар і їхньому перетворенню в макрофаги та пінисті клітини, утворенню великої кількості вільних радикалів. Останні окислюють ліпопротеїди низької щільності, що 
Огляди літератури, оригінальні дослідження, погляд на проблему забезпечує їх перехід через ендотелій в медію і розвиток субклінічного атеросклерозу [12]. Зменшення утворення ендотелієм NO-синтетази має

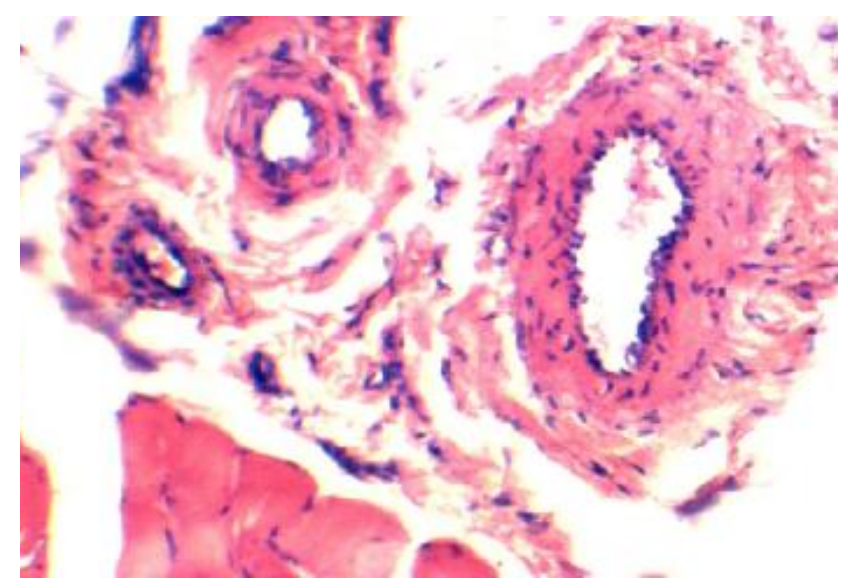

Рис. 2. Гіпертрофія стінки артерії. Гістологічний зріз м'яких тканин гомілки. Забарвлення гематоксиліном i еозином. 36.: ок. -10, об.- 40.

Висновки. 1. Чисельність злущених ендотеліальних клітин суттєво зростає до 30-го дня експерименту, дещо сповільнюється на 45-ий день експерименту та переважає у щурів репродуктивного віку.

2. При експериментальній ГУ спостерігається гіпертрофічно-запальний тип ремоделювання судинного русла, що проявляється в потовщенні су- судинозвужувальну дію і призводить до звуження просвіту артеріального русла і осередкового накопичення пінистих клітин (рис. 3).

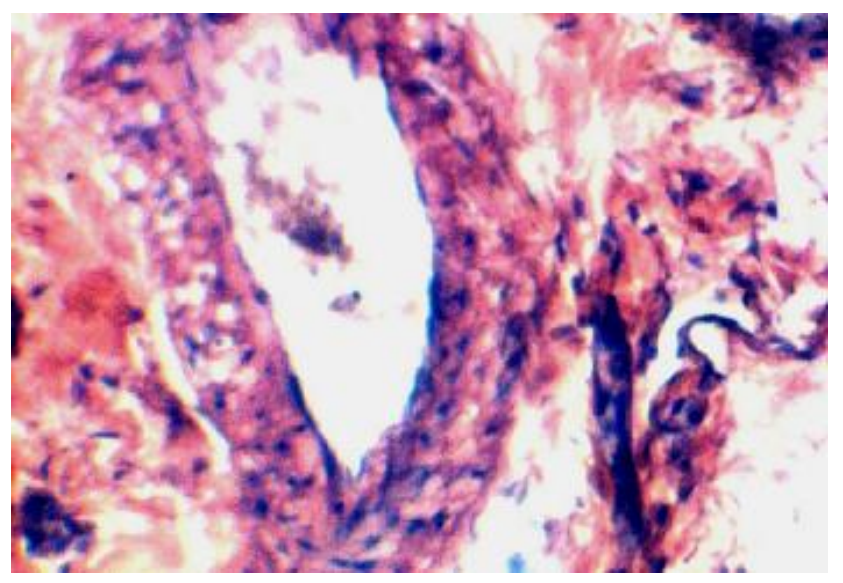

Рис. 3. Наявність пінистих клітин в стінці артерії. Гістологічний зріз м'яких тканин гомілки. Забарвлення гематоксиліном і еозином. 36.: ок. -10, о6.- 40.

динної стінки за рахунок гіперплазії і гіпертрофії лейоміоцитів і лімфоцитарно-макрофагальною інфільтрацією адвентицію.

Перспективи подальших досліджень. 3 метою вивчення та уточнення проявів ремоделювання артерій нижніх кінцівок при ГУ доцільно провести зіставлення структурних змін судин із рівнями в крові ендотелінів.

\section{ЛITEPATУPA}

1. Gagliardi A. C. Uric acid: A marker of increased cardiovascular risk / A. C. Gagliardi, M. N. Miname, R. D. Santos // Atherosclerosis. - 2009. - Vol. 202, № 1. - P. 11-17.

2. Завгородняя А. Н. Структурные особенности сосудистого эндотелия при острых церебральных ишемиях / А. Н. Завгородняя // Международный медицинский журнал. - 2013. - № 2. - С. 21-24.

3. Любин А. В. Функциональное состояние эндотелиоцитов при электротравме в эксперименте / А. В. Любин // Аспирантский вестник Поволжья. - 2013. - № 1-2. C. 192-194.

4. Boos C. J. The relationship of circulating endothelial cells to plasma indices of endothelial damage/dysfunction and apoptosis in acute coronary syndromes: implications for prognosis / C. J. Boos, B. Balakrishnan, A. D. Blann // Thromb. Haemost. - 2008. - № 6. - P. 1841-1850.

5. Závada J. Circulating endothelial cells and circulating endothelial progenitors in kidney disease - victims, witnesses, or accomplices? / J. Závada, L. Kideryová, R. Pytlík // Folia Biol (Praha). - 2008. - № 54 (3). - P. 73-80.

6. Дисфункция эндотелия. Патогенетическое значение и методы коррекции / под. ред. Н. Н. Петрищева. СПб. : ИИЦ ВМА, 2007. -296 с.

7. Kato M. Status of endothelial dependent vasodila- tation in patients with hyperuricemia/M.Kato, I. Hisatone, Y. Tomikura // Am. J. Cardiol. - 2005. - Vol. 96. P. 1576-1578.

8. Takayama S. Uric acid is an independent risk factor for carotid atherosclerosis in a Japanese elderly population without metabolic syndrome / S. Takayama, R. Kawamoto, T. Kusunoki // Cardiovasc. Diabetol. - 2012. Vol. 11. - P. 2-9.

9. Патент 25012 U, Україна. Спосіб визначення вільноциркулюючих ендотеліальних клітин у крові / В. В. Сівак, Н. В. Тимофієва, О. Б. Донник та ін. - № 200702080; заявл. 27.02.07; опубл. 25.07.07., Бюл 6.

10. Синяченко О. В. Эндотелиальная дисфункция сосудов и лечение больных подагрой / О. В. Синяченко, Г. А. Игнатенко, Е. А. Субботина // Український терапевтичний журнал. - 2007. - № 4. - С. 18- 22.

11. Патент України № 97949 UA, G09B23/28, А61К35/14 Спосі6 моделювання гіперурикемії / Боднар Я. Я., Кріпка О. І., Юрик І. І. / ДВНЗ «Тернопільський державний медичний університет імені І. Я. Горбачевського МОЗ України» / Опубл. 10.04.2015 ; Бюл. №7.

12. Ивашкин В. Т. Клиническое значение оксида азота и белков теплового шока / В. Т. Ивашкин, О. М. Драпкина. - М. : ГЭОТАР-Медиа, 2011. - 376 с. 
Огляди літератури, оригінальні дослідження, погляд на проблему

THE DESQUAMATION OF THE ENDOTHELIOCYTES OF THE ARTERIES

OF LOWER LIMBS IN EXPERIMENTAL HYPERURICEMIA IN RATS OF BEFORE REPRODUCTIVE AND REPRODUCTIVE AGE

OI. I. Yuryk', Ya. Ya. Bodnar', M. M. Orel²

${ }^{1}$ SHEI «Ternopil State Medical University by I. Ya. Horbachevsky of MPH of Ukraine»,

${ }^{2}$ Municipal Institution of Ternopil Regional Counsil "Ternopil Regional Autopsy Office»

SUMMARY. In the analysis of the features of endotheliocytes desquamation among animals of before reproductive and reproductive age in conditions of hyperuricemia it was defined that the number of desquamated endothelial cells increases significantly up to the 30th day of experiment and prevails among rats of reproductive age.

The remodeling of the blood flow shows up by thickening of the vascular wall due to the hyperplasia and hypertrophy of the leiomyocytes and lymphocytic and macrophage infiltration of the adventitia.

KEY WORDS: hyperuricemia, desquamated endotheliocytes, remodeling, arteries of the lower limbs.

Отримано 10.11.2015 